Pamiętnik Literacki 2018, 3, s. 146-164

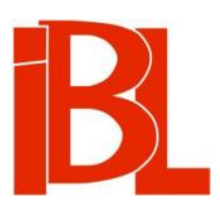

\title{
Nieznane fakty $z$ biografii Jana Parandowskiego
}

\author{
Grażyna Pawlak
}




\section{2. $\begin{array}{llllllllllllllllll} & \mathrm{M} & \mathrm{A} & \mathrm{T} & \mathrm{E} & \mathrm{R} & \mathrm{I} & \mathrm{A} & \mathrm{E} & \mathrm{Y} & \mathrm{I} & \mathrm{N} & \mathrm{O} & \mathrm{T} & \mathrm{A} & \mathrm{T} & \mathrm{K} & \mathrm{I}\end{array}$}

Pamiętnik Literacki CIX, 2018, z. 3, PL ISSN 0031-0514

DOI: $10.18318 / \mathrm{pl} .2018 .3 .10$

GRAŻYNA PAWLAK Instytut Badań Literackich PAN, Warszawa

\section{NIEZNANE FAKTY Z BIOGRAFII JANA PARANDOWSKIEGO}

Jan Parandowski przyszedł na świat $11 \mathrm{~V} 1895^{1}$ we Lwowie, przy ulicy Batorego $30^{2}$. W księgach metrykalnych Cerkwi Wołoskiej za 1895 rok widnieje nota mówiąca o urodzonym $11 \mathrm{~V}$, a $12 \mathrm{~V}$ wpisanym do księgi chłopcu wyznania katolickiego, dwojga imion: Joannes Athanasium, z nieznanego ojca (, illegitimi”) ${ }^{3}$; matka: Julia Parandowska, córka Józefa i Anny Parandowskich z Mościsk; dziecko ochrzczone i pobłogosławione przez Konstantyna Sawrymowicza; rodzice chrzestni: Jan Leńko, właściciel realności, i Maria Bartoszewska, żona Grzegorza ${ }^{4}$; poród przyjęła Maria Lewicka ${ }^{5}$.

Niełatwo znaleźć odpowiedź na pytanie, kim byli rodzice Parandowskiego. Na przełomie wieków księgi adresowe miast dawnej Galicji rejestrowały w swoich spisach wyłącznie obywateli o odpowiednio wysokim cenzusie majątkowym lub wykształceniu ${ }^{6}$. Należeli do nich m.in. właściciele firm, nieruchomości, zakładów usługowych, urzędnicy państwowi, a także profesorowie, nauczyciele, urzędnicy wyższej rangi itp. Duża część mieszkańców napływowych nie była uwzględniana w takich rejestrach. Do tej grupy należała Julia Parandowska, która z Mościsk, gdzie najpewniej się urodziła, przyjechała do Lwowa w poszukiwaniu posady. $Z$ przekazów rodzinnych wiadomo, że jako młoda kobieta znalazła zatrudnienie $\mathrm{w}$ jednej z pracowni modniarskich, czyli u tzw. modystki. Niełatwo dociec, kiedy

1 Błędną datę urodzenia, przesuwając ją na 1893 r., podają S. La m (Wspótcześni pisarze polscy. Literatura piękna, krytyka literacka. Warszawa [1922], s. 35), K. C z a c h ow sk i (Obraz wspótczesnej literatury polskiej 1884-1934. T. 3: Ekspresjonizm i neorealizm. Warszawa-Lwów 1936, s. 56), M. Ruszczy c (Niebo w ptomieniach. „Płomienie” 1958, nr 3, s. 19), R. Matus zew ski (Contemporary Polish Writers. Warsaw 1959, s. 105) i Ž. N. To d or ovi ć (Reč imaju pisci sveta i knjiga. Prevodilac, lektor svih stranih prevoda L. Ra d ovi ć. Kragujevac 1962, s. 201).

2 Na przełomie XIX i XX w. pod tym adresem mieściła się Fundacja im. św. Łazarza. Być może, właśnie tam pracowała siostra Julii Parandowskiej, która była pielęgniarką. Można jedynie przypuszczać, że ze względu na wiek położnicy (35 lat) poród w warunkach domowych obarczony był zbyt dużym ryzykiem.

3 Cerkwa Wołoska, Liber natorum 1891-1902. Centralnyj derżawnyj istorycznyj archiw Ukrajiny u misti Lwowi (Centralne Państwowe Archiwum Historyczne Ukrainy we Lwowie, dawne Archiwum Krajowe Aktów Grodzkich i Ziemskich we Lwowie; dalej: CDIAL), fond 201, op. 4-A, spr. 6822.

4 Maria Bartoszewska była matką ks. prof. Jana Bartoszewskiego i babką Jana Parandowskiego.

5 Wedle przekazów rodzinnych funkcję położnej pełniła Maria Lewicka, młodsza siostra Julii Parandowskiej.

$6 \quad$ Zob. H. Kra marz, Samorzad Lwowa $w$ czasie pierwszej wojny światowej i jego rola $w$ życiu miasta. Kraków 1994, s. 14. 
zamieszkała w mieście nad Pełtwią, ponieważ nazwisko Parandowskiej po raz pierwszy pojawiło się w księgach adresowych Lwowa dopiero, gdy została ona właścicielką nieruchomości przy ulicy Domsa 5 (obecnie: Witowicza).

Udało się odnaleźć zaledwie kilka dokumentów dotyczących matki Jana Parandowskiego. Jednym $z$ nich jest Księga zgonów (Liber mortuorum) ${ }^{7}$ katolickiej parafii św. Elżbiety we Lwowie, do której należeli wierni obrządku łacińskiego mieszkający przy ulicy Domsa $5^{8}$. Odnotowano w owej księdze wiek zmarłej (66 lat), datę i przyczynę zgonu (14 X 1925, uremia) oraz dzień pochówku (16 X 1925). Z zapisu wynika, iż Julia Parandowska była córką Józefa i Anny Parandowskich, osiadłych w Mościskach, i zmarła z powodu choroby wywołanej upośledzeniem nerek. Dokumenty zgromadzone w Państwowym Archiwum Obwodowym we Lwowie, w tym Księga pochowanych (Liber sepultorum), przyniosły także odpowiedź na pytanie o miejsce pogrzebu. Na ich podstawie ustalono, że ciało Julii Parandowskiej zostało złożone w grobowcu rodziny Bartoszewskich, na Cmentarzu Łyczakowskim, bez ujawnienia nazwiska kobiety na płycie nagrobnej ${ }^{9}$. Adnotacja w Księdze zgonów z 1925 roku o wieku zmarłej (66 lat) pozwala wysnuć wniosek, iż urodziła się ona w 1859 roku, prawdopodobnie w Mościskach, tj. w małym miasteczku położonym nieopodal Przemyśla. Inny ważny dokument to księgi metrykalne ludności wyznania katolickiego, w tym księgi konsystorskie parafii Mościska z 1859 roku $^{10}$.

W Księgach zapowiedzi w miejscu dotyczącym rodziców Julii zapisano, że zapowiedzi wnosili narzeczeni: Anna Fedyk, lat 37, obrządku greckokatolickiego, córka Ireny Fedyk, stanu wolnego, oraz Józef Parandowski, lat 27, obrządku łacinskiego, syn Wincentego Parandowskiego i Agnieszki Kuc. Ponadto zaznaczono, iż ślub został zawarty w Mościskach 8 V 1859, a miejscem ceremonii była cerkiew greckokatolicka pod wezwaniem Najświętszej Marii Panny. Natomiast w Księdze ślubów tejże cerkwi znajduje się nieco szersza informacja o obojgu narzeczonych. Dowiadujemy się z niej, że Józef Parandowski był rolnikiem ze wsi Sułkowszczyzna, Anna Fedyk zaś pochodziła z Brześcian w powiecie samborskim. Oboje zatem należeli do stanu włościańskiego. Funkcje świadków zaślubin pełnili także rolnicy: Ignacy Barabak i Andrzej Maygier ${ }^{11}$. W sytuacji, gdy przyszli małżonkowie należeli do różnych wyznań, wedle prawa zwyczajowego udzielano sakramentu małżeństwa w obrządku panny młodej. W księgach chrztu obrządku łacińskiego brak zapisu o chrzcie dziecka. Można zatem domniemywać, że Julia Parandowska została s'koji oblasti Ukrajiny u Lwowi (Państwowym Archiwum Obwodowym Ukrainy we Lwowie; dalej: DALO), wynika, iż grobowiec rodziny Bartoszewskich, oznaczony numerem 229, znajduje się w polu 51. Pochowano w nim cztery osoby: Grzegorza Bartoszewskiego (84 lata, zm. 13 III 1898), Marię Bartoszewska (88 lat, zm. 29 I 1908), Jana Bartoszewskiego (69 lat, zm. 14 XII 1920) oraz Julię Parandowską (66 lat, zm. 14 X 1925). Zob. Liber sepultorum. Cmentarz Łyczakowski. DALO, sygn. 3152/1/33/22. Dane te nie zawsze okazują się precyzyjne, o czym będzie mowa dalej.

10 Księga zapowiedzi parafii Mościska za rok 1859. Archiwum Archidiecezji Przemyskiej (dalej: AAP), nr 26.

11 Zob. Liber copulatorum 1785-1901. CDIAL, fond 201-4a, op. 4-A, spr. 6929 (Księga ślubów cerkwi greckokatolickiej w Mościskach za rok 1859). 
ochrzczona w cerkwi greckokatolickiej ${ }^{12}$. Zgodnie $z$ dopuszczalną i utartą praktyką religijna w rodzinach wielowyznaniowych córki zazwyczaj przyjmowały sakrament chrztu w obrządku matki, natomiast synowie w obrządku ojca.

Pogrzeb matki Jana Parandowskiego odbył się w obrządku łacińskim. Można stąd wnosić, że została ona wychowana wedle tradycji religijnej ojca. W rodzinach wielowyznaniowych dzieci zazwyczaj chrzczono w różnych obrządkach, ale praktykowano w jednym. Ponadto na terenach, na których rywalizowały ze soba prawosławie i katolicyzm, ludność obrządku greckiego nakłaniano, a niekiedy wręcz zmuszano, do przejścia na to pierwsze. W takich przypadkach wierni, aby zachować jedność z Kościołem, wybierali obrządek łaciński.

Jeszcze jedna karta została dopisana przez potomków krewnych Julii Parandowskiej. Otóż z relacji rodzinnych wynika, iż miała ona dwie przyrodnie siostry z drugiego małżeństwa ojca, Marię i Katarzynę ${ }^{13}$. Prawdopodobnie matka Julii, Anna, wcześnie zmarła i dlatego córki $z$ obu małżeństw wychowywano w obrządku ojca. Wedle tej samej relacji wszystkie siostry zamieszkały razem we Lwowie, w domu Jana Bartoszewskiego, przy ulicy Domsa 5.

Parandowski wielokrotnie wspominał, że jako dziecko mieszkał z matką i babką we Lwowie przy ulicy Chorążczyzny 18 (obecnie: Czajkowskiego) ${ }^{14}$. Lektura Ksiag adresowych królewskiego stołecznego miasta Lwowa dostarcza pełniejszej informacji. $Z$ umieszczonych tam zapisów wynika, iż do 1902 roku pod tym adresem zamieszkiwał Jan Bartoszewski, kanonik greckokatolicki, ksiądz doktor, profesor Uniwersytetu Lwowskiego. Od roku 1903 do 1920 stałym adresem księdza kanonika był dom przy ulicy Domsa 5. Potwierdzaja to też znajdujące się w lwowskich zbiorach wizytówki profesora Bartoszewskiego ${ }^{15}$.

We wspomnieniach $\mathrm{z}$ okresu dzieciństwa ${ }^{16}$, jak również w tekstach literackich, pisarz sugerował, że ojciec zmarł w jego wczesnym dzieciństwie, w jednym zaś z utworów przytacza taką oto opowieść matki:

Urodziłeś się nad ranem, ale to się liczyło jakby wczoraj, a dziś był twój chrzest. Ojciec uparł się,

W CDIAL i w Lwowskim Oddziale Archiwum w Mościskach nie udało się odnaleźć ksiag metrykalnych (liber natorum) za lata 1858-1860.

13 Zob. M. Bła huta, list do J. Szczepkowskiej, z 2007. Nadawczyni jest wnuczka jednej z sióstr Julii Parandowskiej, adresatka zaś - wnuczką Jana Parandowskiego. Oryginał listu w zbiorach J. Szczepkowskiej. Relacje potwierdza zachowany w zbiorach rodzinnych akt chrztu Katarzyny Parandowskiej z r. 1878, wydany przez parafię Mościska, w którym zapisano: „Katarzyna, córka małżeństwa Józefa Parandowskiego i Anny Szot, córki Stefana i Eufrozyny z domu Woronow”.

Zob. W. Stu d e n c ki, Alchemik słowa. Rzecz o Janie Parandowskim. Cz. 1. Opole 1972, s. 16. Nieprecyzyjne są zatem informacje zawarte w książce J. Szczepkows ki ej (Kto ty jesteś. Poczatek sagi rodzinnej. Warszawa 2014, s. 37), która podaje tam adres Chorążczyzny 20. Omyłkę powtarza w wywiadach: Inna inaczej niż inni. Rozmawia M. B o r k o w s k i. „Tygodnik Powszechny” 2014, nr 30, s. 59; M H, Joanna Szczepkowska odkryła sekret dziadka. „Życie na Gorąco” 2016, nr 21, s. 14.

15 W doskonałym stanie zachowały się pojedyncze wizy tówki $z$ dwóch różnych adresów zamieszkania: jedna $z$ ul. Chorążczyzny 18 (parter), druga z ul. Domsa 5. Zob. Lwowska Narodowa Naukowa Biblioteka Ukrainy im. W. Stefanyka (dalej: LNNBU), Dział Rękopisów, sygn. II Lbc 132, op. 8.

16 Pierwszy biograf Parandowskiego, G. H a rj a n (Jan Parandowski. New York 1971, s. 2) na podstawie przeprowadzonych z prozaikiem wywiadów napisał: „Parandowski jest powściagliwy w rozmowie o ojcu, nie pamięta go, miał zaledwie dwa lata, gdy ojciec zmarł”. 
żeby ciebie zaraz chrzcić, boś mu się wydawał taki słabiutki, że bał się o twoje życie. Biedaczysko, sam się tak uwinąl, że nie miałeś kiedy go poznać. [Z 136 $]^{17}$

Wobec zebranych materiałów te sugestie należy traktować w kategoriach licentia poetica. Dokumenty archiwalne ${ }^{18}$ oraz opowieści rodzinne wskazuja jednoznacznie, iż ojcem Jana Parandowskiego był Jan Bartoszewski, ksiądz doktor, kanonik Greckokatolickiej Kapituły Metropolitarnej, profesor Uniwersytetu Lwowskiego, który zmarł we Lwowie w 1920 roku, gdy pisarz ukończył 25 lat ${ }^{19}$.

Materiały źródłowe potwierdzają również, że Julia Parandowska i jej syn mieszkali pod tymi samymi adresami co rodzina Jana Bartoszewskiego. Matka przyszłego autora Mitologii zmarła pięć lat po śmierci profesora i - jak już wspomniano została pochowana na Cmentarzu Łyczakowskim we Lwowie, w grobowcu rodziny Bartoszewskich $^{20}$. Spoczywa obok Jana Bartoszewskiego i jego rodziców, Marii i Grzegorza Bartoszewskich. Nie wydaje się możliwe, by w grobowcu wysokiej rangi duchownego greckokatolickiego pochowano kobietę spoza ścisłego kręgu rodziny.

Kim zatem był ojciec pisarza? Najpełniejszym źródłem informacji o Janie Bartoszewskim jest jego rękopiśmienny życiorys z 1888 roku, sporządzony w języku ukraińskim i przechowywany w zbiorach Ossolineum we Lwowie ${ }^{21}$. Na kilku luźnych kartkach szczegółowo została omówiona droga zawodowa księdza. Z zamieszczonych w niej danych biograficznych wynika, iż Jan Bartoszewski urodził się we Lwowie 18 I 1852. Początkowo nauki pobierał w lwowskiej szkole im. św. Elżbiety, następnie uczęszczał do ukraińskiego gimnazjum przy ulicy Akademickiej 1 (obecnie: Prospekt Szewczenki). Studia teologiczne ukończył na Uniwersytecie Wiedeńskim,

Skrótem tym odsyłam do: J. P a r a n d ow s ki, Zegar słoneczny. Warszawa 1978. Ponadto stosuję następujące skróty odnoszące się do książek tego autora: L = Luźne kartki. Wrocław 1967; $\mathrm{N}=$ Niebo $w$ płomieniach. Warszawa 1949; P = Pod zamkniętymi drzwiami czasu. Warszawa 1975; S = Szkice. Seria 1: Warszawa 1953; seria 2: Warszawa 1968. Cyfry arabskie po skrótach wskazują stronice. Cyfry rzymskie po skrócie S - numer serii.

18 Kolejnym ważnym dokumentem jest Karta wpisowa do użytku Dziekanatu Uniwersytetu Lwowskiego, z nazwiskiem Jana Parandowskiego, gdzie w rubryce „Imię i nazwisko, stan i miejsce pobytu ojca (opiekuna)” wpisano: „opiekun ks. dr prof. Jan Bartoszewski”. Zob. DALO, fond 26, op. 15, s. 645 .

19 Poza przywołanym fragmentem Parandowski nigdy nie zabierał głosu w tej sprawie. Dzieci prozaika na temat pochodzenia ojca wiedziały bardzo niewiele lub zgoła nic. W środowisku literackim krążyły rozmaite domysły, ale $z$ rzadka pozostawiały ślad na piśmie. Jednym $z$ nielicznych jest głos A. Wata, który w liście do Cz. Miłosza (z 18 I 1966), wypowiadając się o próbach „załgania autobiografii”, wskazywał właśnie na Parandowskiego. Uważał, iż ten „odciął się doskonale od ojca, Ukraińca-diaka” (Korespondencja. Wybór, oprac., przypisy, posł. A. Kowalczykowa. Cz. 1. Warszawa 2005, s. 426). Bliski współpracownik Parandowskiego, W. Bartoszewski, przyznał, iż o pochodzeniu Parandowskiego wiedział jedynie, „że jest może troszkę powiązane z Ukraińcami, z Kościołem greckokatolickim” (W. B art os z ew s ki, I. S molk a, A. P o m or s ki, Mój Pen Club. Warszawa 2013, s. 17). Brak danych źródłowych sprawiał, że autorzy tekstów biograficznych skłonni byli wypełniać tę lukę, sięgając do Nieba w płomieniach, uchodzącego za powieść nasyconą wątkami autobiograficznymi. Stąd zapewne w haśle słownikowym pojawiło się stwierdzenie, że prozaik był synem „Jana Parandowskiego, urzędnika państwowego, radcy dworu” (A. T u s z y ń s ka, Medaliści olimpijskich konkursów sztuki. W: B. Tuszyński, Polscy olimpijczycy XX wieku 〈1924-2002〉. Współpr. H. Kurzyń s ki, A. Tu s zyńs ka. Wrocław 2004, s. 434).

20 Zob. przypis 9.

21 J. Bartoszews ki, życiorys, z 11 III 1888. LNNBU, Dział Rękopisów, sygn. II Lbc 132, op. 8. 
pod kierunkiem znanego filologa, profesora Franza Miklošiča ${ }^{22}$. W wieku 23 lat otrzymał święcenia kapłańskie w obrządku greckokatolickim, a dwa lata później uzyskał stopień doktora teologiii ${ }^{23}$. Karierę naukową i pracę dydaktyczną związał z Uniwersytetem Lwowskim. W latach 1879-1884 był tam adiunktem na Wydziale Teologicznym i w tym okresie przez dwa lata (1883-1884) pełnił funkcję zastępcy profesora teologii pastoralnej z ukraińskim jako językiem wykładowym. W roku 1885 został profesorem zwyczajnym tego przedmiotu. W informatorach galicyjskich już od 1886 roku ksiądz Bartoszewski jest wymieniany w gronie profesorów lwowskiej uczelni ${ }^{24}$. Wiadomo też, iż kilkakrotnie piastował zaszczytne godności uniwersyteckie: na przełomie lat 1893 i 1894 pełnił obowiązki dziekana Wydziału Teologicznego i dwukrotnie obejmował urząd prodziekana (1896-1897 i 1911). Przez ponad ćwierć wieku wykładał pedagogikę dla studentów teologii obrządku greckokatolickiego (1890-1918/19). W roku 1905 został kierownikiem nowo utworzonego seminarium homiletycznego dla alumnów greckokatolickich ${ }^{25}$.

Równocześnie sprawował wiele godności w greckokatolickim Konsystorzu Metropolitarnym we Lwowie. Od roku 1881 wymieniany był w gronie referentów, jako wikary lwowskiej kapituły metropolitarnej. W 1884 został spowiednikiem greckokatolickiego kościoła katedralnego św. Jura, by po niespełna roku objąć stanowisko pierwszego kaznodziei tego kościoła. W 1895 otrzymał godność kanonika honorowego greckokatolickiego Konsystorza. Wkrótce został powołany na urząd radcy metropolitarnego sądu dla spraw małżeńskich i sądu instancyjnego (1897). Od 1900 pełnił też funkcję egzaminatora synodalnego.

Działalność dydaktyczną rozpoczynał w szkołach lwowskich. W kręgu jego zainteresowań, a także powinności duszpasterskich, pozostawała młodzież. W ro-

Franz Miklošič (1813-1891), słoweński filozof, jezzykoznawca i doktor praw. Profesor filologii słowiańskiej na Uniwersytecie Wiedeńskim. Dwukrotny dziekan Wydziału Filozoficznego oraz rektor tej uczelni (w roku akademickim 1853/54). Członek Wiedeńskiej Akademii Nauk. Opracował gramatykę porównawcza języków słowiańskich, a także słowniki starosłowiańsko-grecko-łacińskie. We wcześniejszej literaturze przedmiotu pojawiają się różne daty uzyskania dyplomu doktora teologii przez J. Bartoszewskiego. Rok 1879 podają B. Barwiń ski (Bartoszewski Jan. Hasło w: Polski słownik biograficzny. T. 1. Kraków 1935, s. 328) oraz A. Szafrański (Bartoszewski Jan. Hasło w: Encyklopedia katolicka. Red. F. Gryglewicz, R. Łukaszyk, Z. Sułowski. T. 2. Lublin 1976, s. 88); natomiast rok 1878 - J. Kr a ci k (Bartoszewski Jan. Hasło w: Stownik polskich teologów katolickich. Red. H. E. Wy c zawski. T. 1. Warszawa 1981, s. 118). Błąd wynika zapewne $\mathrm{z}$ faktu, iż wymienieni autorzy korzystali ze źródła pośredniego, jakim była Historia Uniwersytetu Lwowskiego L. Finkla i S. Sta rzyń skiego (Lwów 1894), w której taka informacja pojawia się na s. 184. Za prawdziwą należy przyjąc datę 1877, zamieszczoną w odręcznym życiorysie samego Bartoszewskiego (op. cit.), powtórzoną zaś w najnowszym ukraińskim opracowaniu: M. Tr e z u b, Bartoszewskij Iwan Grigorowicz. „Ukrajinska żurnalistyka w imienach” t. 10 (2003), s. 23.

24 Zob. Szematyzm Królestwa Galicji i Lodomerii z Wielkim Księstwem Krakowskim na rok 1886. Lwów 1886, s. 323.

25 Na Wydziale Teologicznym Uniwersytetu Lwowskiego seminarium naukowe $z$ homiletyki przy Katedrze Teologii Pastoralnej wprowadzono w roku akademickim 1905/06. Zob. DALO, fond 26, op. 8, spr. 255, 278. - T. Dłu go s z, Rzut oka na dzieje lwowskiego Wydziału Teologicznego. W zb.: Wydziat Teologiczny Uniwersytetu Jana Kazimierza we Lwowie 1918-1933. Lwów 1934, s. 18. J. W ołc zańs ki, Wydział Teologiczny Uniwersytetu Jana Kazimierza we Lwowie 1918-1939. Kraków 2002, s. 7. 
ku 1876 ksiądz Bartoszewski wypełniał obowiązki zastępcy katechety w Wyższej Szkole Realnej we Lwowie ${ }^{26}$, a w 1884 został zatrudniony jako katecheta w IV Gimnazjum we Lwowie, tym samym, do którego wiele lat później posłał swojego syna Jana.

Publikował głównie w języku ukraińskim. Ściśle współpracował z periodykami: „Rus'kyj Sion” (przez pewien czas był nawet jego współredaktorem), „Hałyc'kyj Sion”, „Duszpastyr”, „Pedagogische Blätter”, „Nywa”. W rozprawach i artykułach często podejmował temat wychowania dzieci i młodzieży. Ogłosił także kilka zbiorów kazań (pasyjne, niedzielne, świąteczne, pogrzebowe i majowe).

W dorobku naukowym profesora Bartoszewskiego znajdują się prace zarówno z dziedziny teologicznej, jak i pedagogiki: Pedahohija ruska, abo Nauka o wospytaniju (Pedagogika ruska, albo Nauka o wychowaniu, Lwów 1891; wyd. rozszerz.: 1909), Pastoralna teołohija (Teologia pastoralna, Lwów 1902), Swjate Pys'mo Staroho i Nowoho Zawita z pojasnenjamy (Pismo Swięte Starego i Nowego Testamentu z objaśnieniami, t. 1-7, Lwów 1900-1908). W kwestiach teologicznych był ksiądz przedstawicielem nurtu racjonalistycznego, reprezentatywnego dla Wydziału Teologicznego Uniwersytetu Wiedeńskiego drugiej połowy XIX wieku.

Po odzyskaniu przez Polskę niepodległości nastapiła weryfikacja kadr urzędniczych i naukowych. 7 XII 1918 profesorowie Wydziału Teologicznego otrzymali odpis rozporządzenia Ministerstwa Wyznań Religijnych i Oświecenia Publicznego (MWRiOP), z 4 XI, w sprawie objęcia władzy zwierzchniej nad Uniwersytetem Lwowskim przez rząd polski. W związu $z$ tą zmianą wiceprezydent namiestnictwa we Lwowie polecił wszystkim urzędnikom państwowym złożenie ślubowania na wierność państwu polskiemu ${ }^{27}$. W myśl tych rozporządzeń pod koniec roku akademickiego, $30 \mathrm{~V}$ 1919, profesorowie Wydziału Teologicznego wygłosili nową rotę przysięgi ${ }^{28}$. $\mathrm{Z}$ grona pięciu uczonych pochodzenia ukraińskiego od aktu tego wstrzymali się: ks. prof. Józef Komarnicki, ks. prof. Tytus Myszkowski, ks. dr Teodozy Tytus Hałuszczyński oraz ks. Julian Dzerowicz. Bartoszewski był więc jedynym z tego grona, który nie uchylił się od przyrzeczenia ${ }^{29}$.

We wrześniu 1919 wniósł podanie do MWRiOP o przeniesienie w stan spoczynku. Zmarł w swoim rodzinnym mieście 14 XII 1920, w wieku 68 lat $^{30}$. W pogrzebie

Bartoszewski, op. cit.

Zob. Pismo wiceprezydenta Stanisława Grodzickiego do starostów i dyrektorów Policji we Lwowie i Krakowie, Lwów, 17 maja 1919. DALO, fond 26, op. 8, spr. 421.

Treść przysięgi: DALO, fond 26, op. 5, spr. 907: „Ślubuję Państwu Polskiemu wierność i posłuszeństwo oraz przyrzekam, że z całą świadomością i sumiennością przestrzegać będę obowiązujących ustaw i rozporządzeń, że będę wypełniał obowiązki mego urzędu bezstronnie i bezinteresownie, a unikał wszystkiego, co by mogło przynieść szkodę Państwu, a ujmę stanowi, do którego należę". Zob. też P. St a c h, Wydział Teologiczny w latach 1918-1933. W zb.: Wydział Teologiczny Uniwersytetu Jana Kazimierza we Lwowie 1918-1933, s. 82.

Zob. Sta ch, op. cit., s. 104. Za nieprawdziwe należy więc uznać informacje podawane przez Wikipedię w haśle Jan Bartoszewski (http://pl.wikipedia.org/wiki/Jan_Bartoszewski 〈data dostępu: 17 VII 2018〉), jakoby ks. Bartoszewski „na znak protestu przeciw polonizacji uczelni odszedł od pracy uniwersyteckiej”, powtarzane przez wnuczkę pisarza (S z c z e p k o w s k a, op. cit., s. 41. - Inna inaczej niż inni, s. 59. - M H, op. cit., s. 14).

Datę śmierci przyjmuję za Księgami pochowanych Cmentarza Łyczkowskiego (zob. przypis 9). Niektóre źródła podają 15 XII 1920. Zob. Sta ch, op. cit., s. 104. - Kra cik, op. cit., s. 117. Na 
profesora wzięli udział członkowie Senatu Akademickiego i Rady Wydziału Teologicznego oraz studenci teologii ${ }^{31}$. Na zakończenie ceremonii żałobnej mowę pożegnalna wygłosił dziekan Wydziału, ks. Szczepan Szydelski ${ }^{32}$. Kilka dni później, na posiedzeniu Senatu Akademickiego, rektor Emanuel Machek ${ }^{33}$ w swoim wystapieniu poświęconym zmarłemu profesorowi wspominał jego zasługi dla uniwersytetu i społeczności ukraińskiej, oraz podkreślał:

Był [on] wiernym synem swej narodowości, a dla nas szczerze i życzliwie usposobiony, dlatego także $z$ naszej strony otaczała śp. Zmarłego szczera życzliwość i dlatego żegnaliśmy Go ze czcią ${ }^{34}$.

Ojciec Jana Parandowskiego został pochowany w grobowcu rodzinnym na Cmentarzu Łyczakowskim we Lwowie ${ }^{35}$.

Najwcześniejsza wzmianka o Grzegorzu Bartoszewskim, ojcu Jana Bartoszewskiego i dziadku prozaika, znajduje się we wspomnianym już rękopiśmiennym życiorysie syna, w którym nazwał on rodzica „obywatelem miasta Lwowa”, nie ujawniając jego profesji. Po raz drugi nazwisko Grzegorza Bartoszewskiego pojawia się $\mathrm{w}$ prasie lwowskiej - w roku jego śmierci. W zbiorach Biblioteki Ossolineum zachowały się wycinki $z$ ukraińskich dzienników, informujące o zgonie Grzegorza Bartoszewskiego, ojca profesora lwowskiego uniwersytetu, który zmarł 13 III 1898 we Lwowie, w wieku 86 lat. Pochowany został 15 III 1898 na Cmentarzu Łyczakowskim $^{36}$. Był Ukraińcem, o czym świadczą zarówno nekrologi publikowane w periodykach ukraińskich, jak i tablica nagrobna, na której napisy wykuto w tym języku. To jedyne informacje, które udało się odnaleźć o ojcu Jana Bartoszewskiego i dziadku Jana Parandowskiego.

Literacki obraz babki autora, Marii Bartoszewskiej, pojawia się na kartach opowiadań Zegar stoneczny i Akacja ${ }^{37}$. Z opublikowanego na łamach „Kuriera Lwowskiego" nekrologu wynika, iż zmarła ona 29 I 1908, przeżywszy lat $88^{38}$. Za-

tablicy grobowca rodziny Bartoszewskich na Cmentarzu Lyczakowskim we Lwowie widnieje data 13 XII 1920 i tę podaje także lwowskie pismo „Nywa” z 1921 (z. 2, s. 58), w nekrologu J. Bartoszewskiego.

Zob. St a ch, op. cit., s. 104.

Uchwała Senatu Akademickiego z 21 X 1918 stanowiła, iż na pogrzebie mowy wygłaszał dziekan fakultetu, natomiast rektor - jedynie podczas pochówku osób, które pełniły tę samą funkcję. Zob. Kronika uniwersytetu 1918/1919. DALO, fond 26, op. 13, spr. 964. - Wołczański, op. cit., s. 184.

Emanuel Machek (1852-1930), lekarz okulista. Od roku 1898 profesor okulistyki UJK; w roku akademickim 1921/22 rektor tej uczelni. Światowy autorytet w dziedzinie okulistyki, twórca polskiego programu leczenia jaglicy. Założoną przez niego w 1898 r. Lwowską Uniwersytecką Klinikę Okulistyczna przy ul. Akademickiej 11 (obecnie: Prospekt Szewczenki) zaliczano do czterech najważniejszych klinik na świecie (obok tych w Berlinie, Amsterdamie i Nowym Jorku).

St a ch, op. cit., s. 104.

Według zachowanych dokumentów (zob. przypis 9) w grobowcu rodziny Bartoszewskich pochowana została również Julia Parandowska, jednak nie odnotowano jej nazwiska na kamiennej steli. Zob. Bartoszewski, op. cit.

Jan Parandowski wspomina, iż jego babka pochodziła $\mathrm{z}$ rodziny Grodzickich. Niestety, nie udało się ustalić, czy rzeczywiście jej nazwisko rodowe brzmiało Grodzicka, czy też to wnuk obdarzył ją tym mianem - jednym $z$ najbardziej szanowanych we Lwowie.

Maria Bartoszewska, nekrolog. „Kurier Lwowski” 1908, nr z 30 I, s. 4. 
tem ukochana babka pisarza odeszła, gdy jej wnuk miał lat 13. Została pochowana w grobowcu rodzinnym na Cmentarzu Łyczakowskim we Lwowie ${ }^{39}$.

Wedle przekazów krewnych ksiądz Jan Bartoszewski poznał Julię Parandowską u wspomnianej już modystki. Wnosząc z tejże relacji, Julia Parandowska była kobieta „niezwykłej urody, emanująca szczególnym rodzajem szlachetności”. Obie te informacje znajdują potwierdzenie na kartach wspomnień Parandowskiego z okresu dzieciństwa i młodości ${ }^{40}$. Należało więc poszukać odpowiedzi na pytanie, dlaczego ksiądz greckokatolicki nigdy nie zalegalizował związku z matką swojego dziecka i z jakiego powodu jedyny syn, Jan, nie nosił nazwiska ojca. Rozwiązanie zagadki stanowią reguły obowiązujące księży unickich. Zgodnie z Kodeksem kanonów Kościotów wschodnich księżom katolickim obrządku wschodniego wolno zakładać rodziny przed wstapieniem do stanu duchownego lub w trakcie trwania diakonatu, ale przed otrzymaniem święceń kapłańskich ${ }^{41}$. Jan Bartoszewski poznał Julię Parandowską zapewne już po ich uzyskaniu, co czyniło wejście w prawnie usankcjonowany związek małżeński niemożliwym. Ich syn nie mógł więc nosić nazwiska Bartoszewski ${ }^{42}$. Mimo to, zgodnie $\mathrm{z}$ obowiązującą tradycją religijną, został ochrzczony według obrządku ojca - w cerkwi. Prawdopodobnie również praktykował reguły Kościoła wschodniego, ponieważ na świadectwie ukończenia przez Parandowskiego gimnazjum, w rubryce „Wyznanie”, wpisano: „greckokatolickie”.

Ślady wspomnień $z$ tego okresu odnaleźć można w powojennym dzienniku prozaika:

W siódmym roku życia przeniosłem się na sam skraj działu wód i pierwsze zeszyty szkolne kupowałem w dorzeczu Dniestru. Ta wielka wędrówka odbywała się, nie licząc wozu z meblami, z pomocą tramwaju konnego, który u początku ulicy Gródeckiej brał drugą parę koni, aby ją odprząc przy ul. św. Józefata. [L 123]

Diariuszowe reminiscencje znajduja potwierdzenie we wpisach do ksiag adre-

39 Na steli nagrobnej (inaczej niż w Księgach pochowanych - zob. przypis 9) wyryto, iż Maria Bartoszewska przeżyła lat 90. Dekadę wcześniej, 13 III 1898, w tym grobowcu pochowano jej męża, Grzegorza Bartoszewskiego, ojca Jana Bartoszewskiego.

40 Stwierdzenie to dotyczy opowiadań: Akacja, Brat z wyboru, Figliuolo. Szczególnie w opowiadaniu Brat z wyboru, przedrukowanym w Zegarze słonecznym pt. Powrót bajek, Parandowski opisuje reakcję matki na jego opowieść o zdolnym, ale bardzo biednym uczniu o imieniu Grzegorz, oddanym na czas nauki szkolnej pod opiekę wujostwa, nie stroniących od alkoholu. Matka na drugi dzień udała się pod wskazany adres i, oceniwszy warunki, w jakich przebywa chłopiec, po prostu zabrała go do siebie. Od tego momentu mieszkał on razem $z$ Janem w jednym pokoju - przez cały okres nauki w gimnazjum aż do matury. Niewykluczone, że chodzi o Grzegorza Piłata, ucznia rokrocznie klasyfikowanego na pozycji „szczególnie uzdolniony”, z którym pisarz stracił kontakt podczas pierwszej wojny światowej. Zob. Sprawozdania Dyrekcji C. K. IV Gimnazjum obejmujące lata 1906-1913.

41 W obowiązującym księży greckokatolickich Kodeksie kanonów Kościołów wschodnich tego typu przypadki regulowane są przez stosowne zapisy. Otóż kanon 804 stanowi: „Nieważnie usiłuje zawrzeć małżeństwo ten, kto otrzymał święcenia”. Zob. Kodeks kanonów Kościołów wschodnich. Promulgowany przez Papieża Jana Pawła II. Na stronie: http://diecezja.lublin.pl/kkkw/kkkw/ kan0804.html (data dostępu: 17 VII 2018).

42 O statusie dziecka świadczy adnotacja w Liber natorum, gdzie w rubryce „Pochodzenie” przy nazwisku J. Parandowskiego użyto sformułowania , ,illegitimi", zarezerwowanego dla dzieci urodzonych z tzw. nieprawego łoża, czyli nieślubnych. Zob. Cerkwa Wołoska, op. cit. 
sowych miasta Lwowa. Wynika z nich, że w 1902 roku, gdy przyszły pisarz liczył sobie lat siedem, Jan Bartoszewski został właścicielem nieruchomości przy ulicy Domsa $5^{43}$. Rodzina opuściła dotychczasowe skromne mieszkanie przy ulicy Chorążczyzny 18 i przeniosła się ze ścisłego śródmieścia na jego obrzeża, w pobliże greckokatolickiej katedry św. Jura. Tam Jan, przez bliskich zwany pieszczotliwie Dunkiem, rozpoczał swoją edukacje, a jej miejscem była w tamtym okresie Szkoła Powszechna im. Stanisława Konarskiego, ulokowana w neorenesansowym budynku u zbiegu ulic Leona Sapiehy (dziś: Stepana Bandery) i Wojciecha Kętrzyńskiego (obecnie: Jurija Fedkowycza) ${ }^{44}$. Lata w niej spędzone nie wyróżniają się w relacjach prozaika niczym szczególnym - poza wspomnieniami pierwszej szkolnej nagrody i kary, raniącej uczniowską dumę. O swoim wyróżnieniu Parandowski pisze:

W drugiej lub trzeciej klasie szkoły powszechnej, czyli, jak się wówczas mówiło, ludowej, otrzymałem w nagrodę pilności małą książeczkę w czerwonej oprawie, pt. Grzegorz z Sanoka. Była to powiastka budująca, w której miały się ujawnić cnoty późniejszego humanisty, zaczynającego swój żywot w ubóstwie i gorliwej pracy ${ }^{45}$.

Kara zaś, która na długo pozostała w pamięci małego Dunka, było uderzenie rózgą w dłoń. Matka dowiedziała się o tym dopiero wówczas, gdy jej syn przy powitaniu ostentacyjnie podał dawnemu wychowawcy lewą rękę $z$ komentarzem, że prawa dotad go boli od tamtego uderzenia. W dalszej, pełnej wyrzutów, rozmowie z matką tak oto tłumaczył swoje zachowanie: „Ale on nie tylko mnie uderzył, jeszcze mi nie pozwolił stanąć w szpalerze, jak przejeżdżał [Henryk] Sienkiewicz"46.

W roku szkolnym 1905/06, po złożeniu egzaminów do klasy I I7, Jana Parandowskiego przyjęto do grona uczniów Cesarsko-Królewskiego IV Gimnazjum we

ul. Domsa 5 w Księdze adresowej królewskiego stołecznego miasta Lwowa (Lwów 1903).

44 ż a now s ki e go (Henryk Sienkiewicz. Kalendarz życia i twórczości. Wyd. 3, poszerz., uzup. Oprac. M. B o k s z c zani n. Warszawa 2012, s. 287), pod datą roczną 1905 znajduje się zapis: „W końcu
kwietnia Sienkiewicz bawi w Krakowie i zamierza udać się do Wisły i Lwowa”. Brak zaś informacji, czy wizyta ostatecznie doszła do skutku. Natomiast w artykule S. Fity Sienkiewicz we Lwowie (w zb.: Literatura i jej konteksty. Prace ofiarowane profesorowi Czesławowi Kłakowi. Red. J. Rus in, K. Maciąg. Rzeszów 2005, s. 176) odczytać można informację, iż autor Quo vadis po raz ostatni odwiedził Lwów w 1900 r., goszcząc w nim przez kilka dni (29 IV - 6 V). Dla Sienkiewicza był to rok wyjątkowy, pisarz obchodził wtedy jubileusz 25-lecia pracy twórczej i w wielu miastach Polski, w tym także w stolicy Galicji, odbywały się spotkania z nim. Do Lwowa Sienkiewicz przybył pociagiem. Jak donosił korespondent „Gazety Lwowskiej”: „Wzdłuż całej ulicy Kolejowej aż do ul. Gródeckiej płonęły tysiące smolnych pochodni, oblewając cały przejeżdżający orszak krwawą łuną. To młodzież lwowskich szkół średnich składała w ten sposób hołd największemu współczesnemu pisarzowi” (Sienkiewicz we Lwowie. „Gazeta Lwowska” 1900, nr 99, s. 2). Parandowski nie skończył wtedy jeszcze 5 lat, we wcześniej cytowanym fragmencie wspominał zaś, że pierwsze zeszyty szkolne kupował w wieku lat 7. Być może, już 2 lata przedtem korzystał z jakiejś formy zajęć przedszkolnych? W każdym razie edukację rozpoczął bardzo szybko.

47 W roku 1905, podobnie jak w latach wcześniejszych, egzaminy wstępne do klasy I odbywały się w dwóch terminach: 15 VII i 1 IX. Zob. Sprawozdania Dyrekcji C. K. IV Gimnazjum we Lwowie za rok szkolny 1906, s. 45. 
Lwowie $^{48}$. Szkoła galicyjska przed pierwszą wojna światową była w pełni polska. Kadre nauczajaca stanowili Polacy, wykształceni na uniwersytetach krajowych i zagranicznych, niejednokrotnie łączący pracę pedagogiczną $z$ działalnością naukową. Byli wśród nich: Jan Leciejewski, Juliusz Kleiner, Stanisław Maykowski, Jan Szczepański, Wincenty Śmiałek, Władysław Witwicki. Ogromne wrażenie na gimnazjaliście wywarł Maykowski, choć nie należał do stałych nauczycieli przyszłego pisarza (poza kilkoma lekcjami na tzw. zastępstwach). Dwudziestokilkuletni polonista „Z grzywą włosów nad jasnym czołem” (S II 64) wyróżniał się na tle starszych, siwych profesorów: zawsze uśmiechnięty, skory do żartów, odnoszący się z przyjaźnią do młodzieży. Dodatkowo otoczony nimbem poety (drukował wiersze w lokalnej „Gazecie Wieczornej”), oryginalnie ubrany - w czarna pelerynę i kapelusz o szerokim rondzie - jednoznacznie kojarzył się ze światem młodopolskich artystów pióra i pędzla. Młodzieńcza fascynacja nietuzinkowym profesorem znajdzie po latach swój dalszy ciag w bliskiej współpracy byłego ucznia i podziwianego nauczyciela przy nowatorskiej serii podręczników wydawanej przez lwowskie Ossolineum.

Jeden $\mathrm{z}$ wychowanków szkoły wspomina ją następująco:

Słowo „Polska” nie rozbrzmiewało [tam] tylko frazesem na „wieczorach trzech wieszczów” i na obchodach trzeciomajowych, ale przenikało całą treść tej edukacji naprawdę narodowej i całe życie tej szkoły. Wiedza tam nabywana była obszerna i gruntowna, kto wie, czy nie gruntowniejsza niż nawet później w okresie niepodległości ${ }^{49}$.

Z lektury Sprawozdań dyrekcji C. K. IV Gimnazjum we Lwowie za poszczególne lata wynika, że przynależność placówki do monarchii habsburskiej była w gruncie rzeczy fasadowa, sprowadzała się do wypełniania zobowiązań formalnych, do których zaliczał się udział młodzieży wraz z gronem nauczycielskim w nabożeństwach z okazji rozpoczęcia i zakończenia roku szkolnego, z nieodłącznym hymnem państwowym, oraz w uroczystej, dorocznej liturgii mszy świętej odprawianej w dniach imienin cesarza Franciszka Józefa i cesarzowej Elżbiety, a także w kolejne rocznice jej tragicznej śmierci. Znacznie częściej młodzież uczestniczyła w ceremoniach o charakterze patriotycznym, np. w nabożeństwach żałobnych za poległych bohaterów powstania listopadowego; w obchodach rocznicy uchwalenia Konstytucji 3 maja; w odsłonięciu pomnika Adama Mickiewicza we Lwowie; w dorocznych wieczorkach ku czci trzech wieszczów: Mickiewicza, Juliusza Słowackiego i Zygmunta Krasińskiego, czy też w okolicznościowych akademiach związanych z okrągłymi rocznicami urodzin lub śmierci wielkich Polaków.

Było to gimnazjum męskie o profilu klasycznym, nauczające łaciny i greki, które uzupełniały języki nowożytne, polski i niemiecki, oraz przedmioty tzw. realne.

IV Gimnazjum we Lwowie powstało z wydzielenia w III Gimnazjum im. Franciszka Józefa 12 klas sekcji bernardyńskiej, z polskim językiem nauczania. Działalność rozpoczęło w roku szkolnym 1879/80 w zabudowaniach klasztornych ojców bernardynów oraz w sąsiadującej z tymi zabudowaniami kamienicy przy ul. Łyczakowskiej 1/3. W roku szkolnym 1889/90 placówka otrzymała własny gmach, przy ul. Nikorowicza 2 (obecnie: Profesorska), w pobliżu Szkoły Politechnicznej i kościoła św. Marii Magdaleny. Od kwietnia 1919 na patrona zakładu wybrano J. Długosza - jako wzór wychowawcy świadomego powierzonej mu misji. Odtąd szkoła oficjalnie przyjęła nazwę IV Gimnazjum im. Jana Długosza.

I. Wi en i e w s ki, Kalejdoskop wspomnień. Przedm. W. Tarnaw ski. Londyn 1970, s. 15. 
Taki charakter szkoły podkreślony został przez usytuowanie ogromnego posagu Homera w wielkim przedsionku po prawej stronie. Wszyscy przekraczający progi placówki spoglądali w oblicze autora najważniejszych eposów starożytności. W pamięci Parandowskiego zachował się unikatowy wystrój wnętrza, którego punktem centralnym była, rozciagająca się wzdłuż schodów, galeria pocztu królów polskich (S II 20). Do przedmiotów realnych zaliczano: religię, historię, geografię, matematykę, przyrodę, fizykę, chemię, propedeutykę filozoficzną oraz gimnastykę. Lekcje tej ostatniej obowiazywały uczniów wszystkich klas w liczbie 2 godzin tygodniowo. Ponadto w klasie I do zajęć obligatoryjnych włączano kaligrafię (w liczbie 1 godziny tygodniowo) oraz rysunki (2 godziny).

Przedmioty te stanowiły podstawę wykształcenia ogólnego. Dodatkowo szkoła prowadziła szereg zajęć nadobowiązkowych, takich jak stenografia (na lekcje z tego przedmiotu Parandowski także uczęszczał $\langle Z$ 172〉), języki: angielski, francuski, niemiecki, ukraiński (zwany ruskim), śpiew, a dla pragnących rozwijać zdolności artystyczne - wspomniane kaligrafia i rysunki. Szczególnie wiele uwagi poświęcano nauce nowożytnych języków obcych, na która przeznaczano od 4 do 5 godzin tygodniowo (dla co najmniej dwóch wybranych języków). Od absolwentów wymagano umiejętności swobodnego posługiwania się tymi językami zarówno w mowie, jak i w piśmie. Tendencja do stawiania na pierwszym miejscu nauczania nowożytnych języków obcych była charakterystyczna dla wszystkich gimnazjów klasycznych działających na terenie Galicji. Dbano też o poszerzanie zakresu wiedzy uczniów poprzez tworzenie rozmaitych kółek zainteresowań.

Łaciny uczono przez 8 lat po 6 godzin tygodniowo w klasach I-VI, zatem jej poznawanie uczeń rozpoczynał już w 10 roku życia. W dwóch ostatnich latach, czyli w klasach VII i VIII, liczbę godzin zmniejszano do 5. Język grecki młodzież gimnazjalna zgłębiała przez 6 lat, od klasy III do VIII, w wymiarze 4 i 5 godzin tygodniowo (4 godziny w klasach IV i VI, 5 godzin w klasach pozostałych) ${ }^{50}$. W tygodniu lekcje obowiązkowe wypełniały chłopcom od 27 do 31 godzin. Pozostałą część czasu wolnego mogli oni przeznaczyć na zajęcia dodatkowe oferowane przez placówkę.

Gimnazjaliści klas wyższych czytali oraz omawiali dzieła autorów staro- i nowożytnych w językach oryginałów. Lektury szkolne obejmowały mowy Cycerona, duży wybór dzieł poetyckich doby augustowskiej, urywki tekstów Liwiusza, Tacyta, wybrane tragedie greckie, pisma Ksenofonta, rozprawy Platona, a także niektóre księgi z poematów Homerowskich.

Wiedzę nabywaną w galicyjskich gimnazjach, obszerną i gruntowna, szczególnie w zakresie humanistyki, cechował szeroko rozumiany uniwersalizm. „Nic dziwnego" - pisał wieloletni dyrektor gimnazjum Parandowskiego - „że z tak wszechstronnie założonej szkoły wychodził nasz wychowanek uzdolniony do podjęcia wszelkich zadań, jakie nań życie nakładało" 51 .

O wyborze miejsca edukacji przyszłego prozaika zdecydował zapewne jego ojciec, 1906-1913.

51 W. Ś mi ałe k, Pót wieku pracy naukowo-wychowawczej. W: Księga pamiatkowa 50-lecia Gimnazjum im. Jana Długosza we Lwowie. Red. W. Ku c har s ki. Lwów 1928, s. 4. 
który w roku szkolnym 1882/83 pełnił w IV Gimnazjum obowiązi zastępcy katechety religii greckokatolickiej, a rok później był zatrudniony jako katecheta ${ }^{52}$. Miał więc sposobność, by szczegółowo zapoznać się z programem instytucji, ocenić poziom intelektualny kadry nauczającej oraz dowiedzieć się, jakie cele wyznaczała sobie placówka, powołana zaledwie 4 lata wcześniej. Sam gruntownie wykształcony, duchowny pragnał zapewne tego samego dla swojego jedynego syna, wykazującego duże zdolności. W chwili wybierania dlań szkoły był już profesorem na Wydziale Teologicznym Uniwersytetu Lwowskiego oraz pełnił funkcję egzaminatora synodalnego w Greckokatolickim Metropolitarnym Konsystorzu Lwowskim. Miał zatem wystarczającą wiedzę o działających w mieście placówkach, a także możliwości finansowe, które pozwalały posłać potomka do każdej z nich ${ }^{53}$. Sam w młodości zaznał skromnego życia ${ }^{54}$, pragnął więc zapewnić swojemu dziecku łatwiejszy start $\mathrm{w}$ dorosłość. Własne zatem doświadczenia determinowały wybór. Bartoszewski postawił na rozległa i solidną edukację jedynaka, a IV Gimnazjum zaliczane było do najlepszych we Lwowie.

4 IX 1905 10-letni Dunek uroczystym nabożeństwem w kościele parafialnym pod wezwaniem św. Marii Magdaleny rozpoczął 8-letnią naukę w IV Gimnazjum we Lwowie. Ubrany w granatowa bluze $z$ aksamitnymi wyłogami, szare spodnie i granatowe pończochy, sukienną czapkę rogatywkę koloru granatowego, $z$ aksamitnym granatowym otokiem, błyszczaccym daszkiem oraz srebrną litera „G” i z numerem gimnazjum - „IV”55, codziennie pokonywał niewielki odcinek dzielący jego dom od budynku szkoły, usytuowanego przy ulicy Nikorowicza 2 (obecnie: Profesorska). Spotkał tam - jak już wspomniano - znakomite grono pedagogów. Dyrektorem był radca szkolny, doktor filologii Karol Petelenz ${ }^{56}$, powołany na to stanowisko w roku szkolnym 1904/05. W roku następnym przeszedł w stan spoczynku, by otworzyć własna placówkę edukacyjną, czerpiącą z wzorców angielskich ${ }^{57}$. Drugim i ostatnim dyrektorem gimnazjum za czasów szkolnych Parandowskiego był (wzmiankowany wcześniej) doktor Smiałek ${ }^{58}$, znakomity pedagog oraz filolog o wysokiej kulturze

Zob. W. Ku c h a r s ki, Przeglad historyczny 50-lecia Gimnazjum IV im. Jana Długosza we Lwowie. W zb.: jw., s. 49.

Opłata szkolna za ucznia, którą należało uiścić w pierwszych 6 tygodniach półrocza, wynosiła 40 koron. Ponadto uczeń winien był złożyć przy wpisie 2 korony jako datek na zbiory naukowe oraz 1 koronę na cele zabaw szkolnych, uczniowie nowo wstępujący do Zakładu wnosili zaś opłatę wstępną w kwocie 4 koron, 20 halerzy. Zob. Sprawozdania Dyrekcji C. K. IV Gimnazjum we Lwowie za rok szkolny 1910, s. 130.

O tym fakcie świadczą podania do Rady Wydziału Teologicznego o zaliczkę w kwocie 200 zł, rozłożoną na spłaty w 20 miesięcznych ratach. Zob. Pismo Jana Bartoszewskiego z 9 maja 1888 r. DALO, fond 26, op. 5, spr. 71 .

Zob. Parand ow ski, Brat z wyboru, s. 1-2.

Karol Petelenz (1847-1930), doktor filologii, dyrektor szkół w Sanoku, Stryju i we Lwowie. Autor podręczników do nauki języka niemieckiego. Członek Komisji dla Historii Oświaty w Polsce w Akademii Umiejętności w Krakowie. Zastępca Przewodniczącego Szkolnej Rady Okręgowej we Lwowie. Twórca prywatnego Gimnazjum Męskiego im. Adama Mickiewicza we Lwowie.

Chodzi o prywatne Gimnazjum Męskie im. Adama Mickiewicza, typu humanistycznego, którego właścicielem był Karol Petelenz. Szkoła działała w latach 1906-1919. Uczęszczała do niej zamożna młodzież. Wśród innych gimnazjalistów grono to nie cieszyło się sympatią, a od inicjałów na czapkach, „AM”, złośliwie nazywano je „Akademią Matołków”.

Wincenty Śm i ałe k (1863-1943), filolog klasyczny. Od roku 1899 nauczyciel gimnazjalny w szko- 
literackiej. „Jako dyrektor nad wszystko umiłowanej przez siebie szkoły podniósł ją na wyżyny największego rozwoju w całej jej historii” - pisał po jego śmierci Wiktor Hahn ${ }^{59}$. To za kadencji Śmiałka przeżywał przyszły autor Mitologii swoje pierwsze fascynacje naukowe i porażki, w tym również zagrożenie karnym wydaleniem w klasie VI. W murach owej szkoły poznał też wspomnianego już Witwickiego, doktora filozofii, nauczającego - z woli Petelenza - pierwszoklasistów matematyki. Po wielu latach stało się to tematem żartobliwych uwag, wymienianych między byłym uczniem a dawnym mistrzem, na temat dyrektora i jego zaskakujących decyzji. Pierwszy rok w IV Gimnazjum zakończył Parandowski ze stopniem celują$\operatorname{cym}^{60}$.

Następne lata edukacji nadal pozwalały mu osiagać stopień pierwszy w klasyfikacjach. Wyjątek stanowiła tylko klasa VI. Wówczas to, za sprawą nauczyciela języka greckiego, Władysława Bojarskiego, Parandowski został zakwalifikowany do egzaminu poprawkowego $z$ tego przedmiotu. W sprawozdaniach dyrekcji za 1911 rok nazwisko Parandowskiego nie pojawia się w wykazie uczniów klasyfikowanych. Zapewne znalazło się $\mathrm{w}$ grupie gimnazjalistów „przeznaczonych do egzaminu poprawkowego", jednak w dokumentach szkolnych personaliów tej grupy uczniów nie ujawniano ${ }^{61}$. Wspominając ową historię po bez mała ćwierć wieku, autor Mitologii wyznał:

Tej przygodzie zawdzięczam znajomość języka greckiego, którego podstawy zdobyłem wówczas za cenę wakacji. Odtąd znów szedłem w górę, w ósmej klasie należałem do najlepszych uczniów ${ }^{62}$.

Wobec owego sprawcy swoich kłopotów, w gwarze uczniowskiej określanego mianem Doksa, który całe życie uczył greki i stenografii, zachował Parandowski szczególny sentyment. Tym większy, gdy okazało sie - w trakcie przygodnego spotkania w lwowskiej kawiarni - że Bojarskiemu nigdy nie było dane odwiedzić wymarzonej Grecji. Stary nauczyciel po latach z niekłamanym zachwytem słuchał opowieści dawnego ucznia o niepowtarzalnym blasku słońca Hellady63.

Nie zostały jeszcze wspomniane wszystkie kłopoty, jakich doświadczał Parandowski na dwa lata przed ukończeniem gimnazjum. Poważniejszy w skutkach okazał się kolejny „występek”, w którego wyniku przyszły pisarz został zawieszony w prawach ucznia i wyłącznie zabiegom najbliższych zawdzięczał pozostanie w szkole. Rzecz dotyczyła drobnego z pozoru przewinienia. Otóż 27 IV 1911 upublicznio-

łach lwowskich. W latach 1907-1929 dyrektor IV Gimnazjum im. Jana Długosza we Lwowie; członek tamtejszego Towarzystwa Filologicznego oraz Polskiego Związku Historyków Sztuki w Krakowie. Współpracownik Polskiej Akademii Umiejętności w Krakowie.

W. Ha h n, Wincenty Śmiałek. „Pamiętnik Literacki” 1946, z. 3/4, s. 392. Opinię tę potwierdziła

J. Łukaszewska-Haberkowa (Śmiatek Wincenty. Hasło w: Polski słownik biograficzny.

T. 51/1. Kraków 2016, s. 56).

60 Zob. Sprawozdania Dyrekcji C. K. IV Gimnazjum we Lwowie za rok szkolny 1906, s. 45.

61 Zob. Sprawozdania Dyrekcji C. K. IV Gimnazjum we Lwowie za rok szkolny 1911, s. 94.

62 Jak się uczyli wspótcześni, wybitni pisarze polscy. Jan Parandowski. „Wiadomości Literackie” 1936, nr 11, s. 7.

63 Parandowski sportretował swojego profesora w opowiadaniu Doksa, zamieszczonym w zbiorze Zegar słoneczny. W. B oj a rs ki jest także autorem pierwszego Podręcznika stenografii polskiej. Według systemu Gabelsbergera-Polińskiego (Lwów 1909). 
no obwieszczenie władz królewskiego stołecznego miasta Lwowa, zabraniające - pod karą administracyjną - właścicielom szynków, restauracji, kawiarni, cukierni, bufetów itp. przyjmować w lokalach młodzież szkolną. O obowiązku przestrzegania powyższego zarządzenia informowała Rada Szkolna Krajowa specjalnym pismem Z 4 V $1911^{64}$. Nietrudno sobie wyobrazić, jak młodzież na to zarządzenie zareagowała. Lokale, owoc zakazany, stały się przedmiotem szczególnego zainteresowania. Obecność uczniów w takich miejscach nauczyciele traktowali jako poważne wykroczenie przeciw dyscyplinie, a na winowajców czekały surowe kary, włącznie z relegowaniem ze szkoły. Winnym złamania tego właśnie zakazu i ofiarą wynikajacych stąd problemów stał się 16-letni wówczas Parandowski. Po raz pierwszy w życiu przekroczył próg kawiarni, a już następnego dnia wieść o tym dotarła do dyrektora. Wezwany do gabinetu młodzieniec usłyszał: „Nie szanujesz munduru... Nie szanujesz gimnazjum... Nie jesteś godny być tu dłużej” (Z 206). Jednak przygoda owa zakończyła się dla Parandowskiego pomyślnie. Wiele lat później opisał on ją w opowiadaniu Mona Lisa. Wynika $z$ niego, iż pozostanie w szkole zawdzięczał interwencji matki u dyrektora placówki ${ }^{65}$.

W następnym roku szkolnym, już jako uczeń klasy VII, włączył się w prace gimnazjalnego kółka literackiego. Dla jego słuchaczy wygłosił swoje pierwsze referaty: Liceum wotyńskie $w$ Krzemieńcu, Dziady wileńskie i Filozofia Mickiewicza, odnotowane w dorocznych sprawozdaniach szkoły ${ }^{66}$. Można jedynie przypuszczać, że odbyło się to w czytelni, jak bowiem wspominał niewiele starszy od Parandowskiego uczeń tego samego gimnazjum:

Każda niemal szkoła [na terenie Galicji] posiadała taką czytelnię. Jeśli profesor opiekujący się $\mathrm{z}$ ramienia szkoły taką czytelnią był postępowy, to czytelnia stawała się terenem dyskusji na tematy literackie, społeczne, polityczne i artystyczne ${ }^{67}$.

Wstęp na takie spotkania miała także młodzież z innych szkół. Tytułem wyjaśnienia należy dodać, że jednym $z$ opiekunów czytelni w gimnazjum przy Nikoro-

Zob. Sprawozdania Dyrekcji C. K. IV Gimnazjum we Lwowie za rok szkolny 1911, s. 52.

Czy w istocie była to interwencja matki, gospodyni domowej, która w rozmowie $\mathrm{z}$ dyrektorem nie mogła dysponować bogatym zasobem argumentów? Może jednak należy uważniej przyjrzeć się passusowi z Nieba $w$ płomieniach zawierającemu opis dnia, w którym szkołę odwiedza ojciec Teofila Grodzickiego, radca dworu Albin Grodzicki, by bronić syna przed relegowaniem z gimnazjum: „Było wpół do pierwszej. Zakład trwał w tępej ciszy, jaka poprzedza zakończenie ostatniej godziny. Grodzicki rozejrzał się po pustych korytarzach i podniósł wzrok ku schodom prowadzącym na drugie piętro, gdzie po smudze światła z południowych okien wędrowały ruchliwe pyłki kurzu. Znał smak tej pory dnia, suchy i cierpki, jak kredy, znał jej zapach metaliczny, jak atramentu, czuł ją w dotyku, gdy wszystko wydaje się szorstkie, a palce niecierpliwie skubią pod ławką rzemień, którym za chwilę obwiąże się książki i kajety, aby je zanieść do domu. Serce ścisnęło mu się na myśl, że miałaby to być dla Teofila ostatnia godzina w tych murach, i postanowił go ratować za wszelką cenę" (N 154). Do rozmowy z dyrektorem placówki Albin staje więc jak równy z równym, z potyczki z księdzem także wychodzi zwycięsko. Zna swoją wartość i jest partnerem w dyskusji, doskonale zorientowanym w obowiązujących zasadach. Czy nie tak mogło przebiegać spotkanie dawnego katechety, obecnie: profesora uniwersytetu, J. Bartoszewskiego, występującego w roli obrońcy syna, z dyrektorem Gimnazjum?

67 E. Se mi il, Przed druga wojna była pierwsza. Wspomnienia uczestnika rewolucji. Warszawa 1965, s. 35 . 
wicza był młody wówczas polonista, dawny wychowanek placówki i późniejszy profesor Uniwersytetu Jagiellońskiego - wspomniany już Kleiner.

W IV Gimnazjum dużą wagę przykładano do kultywowania pamięci o wielkich Polakach i o wydarzeniach istotnych dla narodu. W Kronice zakładu dołączonej do rocznych Sprawozdań dyrekcji C. K. IV Gimnazjum we Lwowie znaleźć można informacje o rozmaitych uroczystościach, w których obowiązkowo brali udział uczniowie. Sa w niej zapisy o uczestnictwie młodzieży w ostatniej drodze Marii Konopnickiej (11 X 1910), w spotkaniach upamiętniających życie i twórczość Fryderyka Chopina (13 XI 1911) czy w jubileuszowych obchodach setnej rocznicy urodzin Krasińskiego (9 III 1912). Tego typu działania, inicjowane i utrwalane przez szkołę, niewątpliwie wpływały na rozbudzanie zainteresowań uczniów. Niewykluczone, że ich refleksem jest, zamieszczona na łamach „Polskiego Uniwersum” (1912, nr 6), rozprawa Znaczenie narodowych wieszczów, którą Parandowski napisał, będąc w ostatniej klasie gimnazjalnej.

O umiejętnościach językowych gimnazjalisty Parandowskiego świadczy fakt, iż czuł się on na tyle swobodnie, by w klasie VII przystąpić do tłumaczenia Ideen zur Philosophie der Geschichte der Menschheit Johanna Gottfrieda Herdera oraz jednego z tekstów Arthura Schopenhauera - dialogu poświęconego religii. Lecz praca translatorska nie zaprzatała uwagi młodzieńca tak dalece, by zechciał on ją kontynuować. W jednym ze szkiców już u schyłku życia wspominał:

Zaczałem tłumaczyć jeszcze w gimnazjum, ale potem poniechałem i widzę jeszcze zeszyt do połowy zapisany, który latami wałęsał się wśród papierów w moim biurku, póki się nie rozsypał garstką popiołów, gdy rodacy Herdera spalili moje mieszkanie. [P 74]

Dla ucznia zainteresowanego literaturą 1912 rok miał szczególne znaczenie. Przynosił dwie ważne dla świata kultury rocznice: 100-lecie urodzin Krasińskiego i 200-lecie urodzin Jeana-Jacques'a Rousseau. W związku z jubileuszem autora Nie-Boskiej komedii pojawił się na łamach lwowskiego dziennika „Przegląd” cykl artykułów pióra Parandowskiego poświęconych polskiemu romantykowi ${ }^{68}$. Tę publikację należy traktować jako udokumentowany debiut pisarski ${ }^{69}$. Według wspomnień samego autora nie był to wszakże jego pierwszy tekst ogłoszony drukiem. Gimnazjalista miał już za sobą dawniejsze próby literackie, za które jako uczeń był wynagradzany biletami do teatru, a na wakacje otrzymywał karte kolejowa na bezpłatny przejazd pierwszą klasą przez całą monarchię austro-węgierska, od Lwowa do Triestu ${ }^{70}$. Swoje ówczesne umiejętności literackie oceniał po latach $z$ właściwym sobie humorem:

Byłem nieposkromionym grafomanem. Zacząłem od epiki, pisałem poemat, którego akcja toczyła

J. Pa ra n d ow s ki, Zygmunt Krasiński. „Przegląd” 1912, nry 46-49.

Rok 1912 jako datę debiutu podaje Parandowski w opatrzonej własnoręcznym podpisem Ankiecie członkowskiej Związku Literatów Polskich z 1 III 1952. Zob. Teczka osobowa „Jan. Parandowski”. Biblioteka Donacji Pisarzy Polskich w Domu Literatury, nr inw. 1853.

Niewykluczone, że były to honoraria za teksty publikowane w 1912 r. na łamach „Polskiego Uniwersum” (Znaczenie narodowych wieszczów), i „Przeglądu” (Zygmunt Krasiński oraz Tragicy greccy). Poza wspomnianymi artykułami, mimo szerokiej kwerendy, innych sygnowanych tekstów Parandowskiego nie udało się odnaleźć. 
się na Borneo, wśród szczepu Dajaków. Bohaterowi dałem imię Sfodra, biorąc je po prostu ze słownika greckiego; jest to przysłówek, znaczy: 'gwałtownie, namiętnie'... Gdyby zachowały się te wszystkie kartki i świstki, na których kropiłem swoje trzynastozgłoskowce, zebrałaby się całość o rozmiarach Mahabharaty. Każdy poeta czytany w szkole, każdy utwór „wpływał” na mnie natychmiast: pisałem liryki, dramaty, ballady, sielanki, bajki, nawet gawędy w guście [Wincentego] Pola. Jeden z zeszytów tych wierszy ocalał, jeśli zajrzeć do niego - ciarki człowieka przechodzą. Lecz wśród kolegów uchodziłem za poetę i cieszyłem się u nich pewnym szacunkiem. Zawdzięczałem to podstępowi, który niejednego grafomana ratował $\mathrm{z}$ opresji: pisałem bałamutnie, z pozorami „głębi” ${ }^{\prime \prime}$.

Owe pierwociny literackie nie przetrwały próby czasu, ich ślady można odnaleźć wyłącznie w szkicu Moje poczatki literackie:

Ani jeden wiersz nie ocalał. Przyszła pora na inne, może lepsze, a może tylko bardziej dostosowane do smaku naszych czasów, dość, że zdobyły mi [one] w całym czwartym gimnazjum trwałą reputacje poety. [S I 12]

Po opublikowaniu cyklu artykułów o Krasińskim redaktor lwowskiego „Przeglądu”, Ludwik Masłowski ${ }^{72}$, zamówił u Parandowskiego podobne opracowanie $\mathrm{z}$ okazji przypadającej w tym samym roku 200 rocznicy urodzin Rousseau. Propozycja, aczkolwiek wielce zaszczytna, wywołała popłoch młodego pisarza. Perspektywa łączenia nauki szkolnej ze studiowaniem dzieł francuskiego myśliciela rysowała się niezbyt zachęcająco. W przypadku szkiców o Krasińskim zadanie okazało się nieco łatwiejsze, ponieważ jego dzieła należały do kanonu lektur szkolnych, natomiast twórczość autora Umowy społecznej daleko wykraczała poza zakres wiedzy gimnazjalisty. Niepodobna było jednak odmówić. Co ciekawe, redaktor periodyku nie zdawał sobie sprawy, że autor felietonów jest jeszcze uczniem. Młody zaś człowiek nie miał odwagi pojawić się w redakcji w gimnazjalnym mundurku. Doskonałego rozwiązania w tej sytuacji dostarczyła poczta, dzięki której Parandowski mógł przesyłać teksty bez konieczności osobistego stawiania się w siedzibie „Przeglądu”. Nieoceniona pomoca w pracy okazały się zasobne zbiory Ossolineum. Czytelnia lwowskiej książnicy była miejscem, gdzie przyszły autor Mitologii sumiennie studiował dzieła genewskiego filozofa. W stosunkowo krótkim czasie powstała rozprawka Rousseau. Szkic literacko-filozoficzny. Musiała zyskać niemałe uznanie w oczach redaktora pisma, gdyż zdecydował się on wydrukować ją na pierwszej stronie, w kilkunastu kolejnych numerach dziennika ${ }^{73}$.

Po zaledwie paru miesiącach tekst wydano w postaci „osobnej odbitki $z$ "Przeglądu ". Co do użycia tej formuły, miał Parandowski zastrzeżenia. Po latach wyznawał: „Do dziś nie wiem, czy szkic miał prawo tak się nazywać, nie był bowiem wzięty ze składu gazety, ale na nowo złożony i odbity u Szyjkowskiego na [ulicy] Zimorowica" 74 .

Była to pierwsza książka Parandowskiego. Ukazała się wiosną 1913, na kilka

Jak się uczyli wspótcześni, wybitni pisarze polscy. Jan Parandowski, s. 7.

Ludwik Masłowski (1847-1928), publicysta, tłumacz, redaktor. Weteran powstania styczniowego. Studiował medycynę i nauki przyrodnicze w Paryżu. Po powrocie do Polski podjął działalność wydawniczą we Lwowie. Tłumacz prac Ch. Darwina (O pochodzeniu człowieka, Dobór płciowy). Był pierwszym redaktorem „Kuriera Lwowskiego” oraz lwowskiego dziennika „Przegląd” (1912-1914). „Przegląd” 1912, nry 260-278.

J. P a r a n d ow ski, Juvenilia. Warszawa 1960, s. 10-11. 
tygodni przed maturą. W jego karierze pisarskiej miała szczególną rangę - stanowiła pierwszą pozycję samoistną wydawniczo i, co ważniejsze, powstała na specjalne zamówienie, złożone bardzo młodemu przecież człowiekowi. Na kilkudziesięciu stronicach debiutant zdołał przedstawić barwny portret genewskiego myśliciela i główne kierunki jego zainteresowań. Już od chwili powstania szkicu Parandowski cenił tę pracę dość wysoko. Nawet po wielu latach wyraźnie pamiętał wzruszenie, jakie ogarnęło go na widok pierwszej w życiu recenzji ${ }^{75}$. Jej autor, Julian Sławkowski, choć odnotował pewne potknięcia, pochwalił umiejętności warsztatowe Parandowskiego oraz podkreślił piękno jego stylu, nazywając go wprost „poetycznym”. W dalszej części tekstu dodawał:

Trzeba bardzo kochać prawdę, aby o człowieku, o którym tak wielu ludzi ma wysokie wyobrażenie, powiedzieć, że razem ze swymi pozorami nauki był nieukiem, ze swoimi porywami do pisania powieści lichym powieściopisarzem; aby to powiedzieć, trzeba mieć odwagę wystapić przeciw zakorzenionym jak przesąd mniemaniom. Wielkie zrozumienie całej zagadkowej postaci genewskiego myśliciela wykazał autor, kreśląc żywot jego w przytoczonej rozprawie ${ }^{76}$.

Wedle wspomnień samego Parandowskiego jeszcze głębszym przeżyciem było dlań spotkanie $\mathrm{z}$ wydawcą:

Miałem odbyć pierwszą w życiu rozmowę [...] o honorarium. Było ono umówione „w miarę rozprzedaży” - z jowialną mglistością, właściwą [Alfredowi] Altenbergowi. Gdy mu teraz wyjaśniłem cel mojej wizyty, najpierw się zmarszczył, potem przyjrzał mi się uważnie (byłem już na uniwersytecie), przypomniał sobie, że ostatni raz widział mnie w mundurze z czterema złotymi paskami, zawołał: „A to heca!”, i pobiegł na pięterko, gdzie były biura. Wodząc spojrzeniem po galeryjce zawieszonej nad księgarnią, czułem się jak Filon z Aleksandrii na audiencji u Kaliguli. Altenberg wrócił po kwadransie, w najświetniejszym humorze. Podał mi obliczenie $z$ rozprzedaży i sam poszedł do kasy, gdzie wypłacił mi $z$ góra trzysta koron. Był to niewątpliwie cud, że taka kwota znalazła się pod ręką; jak wielki cud, zdołałem [...] zrozumieć dopiero w osiem lat później, gdy jako kierownik literacki firmy poznałem jej interesy, prowadzone z czarującą niefrasobliwością. [S I 14-15]

Zainteresowanie nauką wyniósł Parandowski z domu rodzinnego, w którym jak można sądzić - przewodnikiem po meandrach myśli filozoficznej był dla chłopca ojciec. To zapewne $z$ jego inspiracji syn, będąc jeszcze uczniem gimnazjum, prenumerował periodyk „Eos”, założony i redagowany przez Ludwika Ćwiklińskiego, ówczesnego prezesa Towarzystwa Filologicznego. W ostatniej klasie angażował się już w prace szkolnego kółka filozoficznego i na jego forum wygłaszał referaty poświęcone rozmaitym nurtom tej dziedziny, w tym przedsokratykom, na podstawie podręcznika Historia filozofii greckiej autorstwa Stefana Pawlickiego. O dogłębnym przestudiowaniu książki świadczy liczba prelekcji Parandowskiego. W szczegółowych sprawozdaniach dyrekcji odnotowano je wszystkie - w sumie $14^{77}$. Panująca w domu atmosfera szacunku dla wielowiekowej tradycji filozoficznej sprawiła, iż z czasem ten świat, odległy i fascynujący, stał się nieodłączną częścią osobistego doświadczenia przyszłego autora Mitologii. Na kształtowanie się umysłowości młodzieńca

Zob. ibidem, s. 14

J. Sła wkowski, Parandowski Jan, „Rousseau. Szkic literacko-filozoficzny”. „Książka” 1913, nr 12, s. 634-635.

Sprawozdania Dyrekcji C. K. IV Gimnazjum we Lwowie za rok szkolny 1913, s. 58. Niestety, tytułów prelekcji nie podano. 
niebagatelny wpływ miała zapewne zasobna biblioteka znajdująca się w domu rodzinnym. Ozdobą owego księgozbioru było dzieło wzmiankowanego już krakowskiego filozofa, które po latach stało się tematem osobnego szkicu wspomnieniowego:

Ta książka była zawsze w naszym domu, w oszklonej szafie, i przez całe dzieciństwo patrzyłem na nią: tom w czarnej płóciennej oprawie ze złotymi literami na grzbiecie. Kiedy umiałem je odczytać, okryły się nową tajemnicą: Pawlicki - Filozofia grecka. I tak z roku na rok rosłem z zagadką, która w niewytłumaczony sposób kusiła mnie i zatrzymywała moją uwagę. W pewien wieczór ktoś z gości przy kartach wymówił nazwisko: Pawlicki, ojciec Pawlicki, i przez kilka minut opowiadał o ciekawej postaci, znanej wszystkim w Krakowie. Miałem już dwanaście lat, słuchałem uważnie. [P 69]

Znaczący wpływ na gimnazjalistę wywarł też wzmiankowany wcześniej Szczepański, nauczyciel języków starożytnych, który dokładał wszelkich starań, by odsłonić uczniom piękno prozy łacińskiej. Czynił to za pośrednictwem jednego $z$ jej największych twórców - Cycerona. Właśnie on przez artyzm swoich dzieł oraz ich ładunek kulturalny szczególnie przykuwał uwagę profesora, który z myślą o uczniach szkół średnich przygotował Wybór mów (1913) oraz Wybór z pism retorycznych, filozoficznych $i$ listów tego autora (1914). Ambicję pedagoga stanowiło łączenie nauki języka $z$ poznawaniem kultury rzymskiego antyku. Lekcje łaciny Szczepańskiego stawały się szkołą dialogu, w którym każdy z uczestników miał swój udział. Tak o zajęciach odbywanych pod kierunkiem tego prowadzącego pisał po latach inny jego wybitny uczeń, Jan Legowicz:

Była to koncepcja nauczania łaciny jako rozumnego wysłowiania językowego, a nie języka jako takiego, koncepcja, według której język jako układ znaków nie zamyka się tylko w składni czy gramatyce lub w formalnie poprawnej komunikatywności, ale że jest przekazywaniem nurtujących myśl treści i środkiem we współuczestniczeniu kulturowym ludzkości. Dlatego, ucząc się tzw. „słówek”, uczyliśmy się u Szczepańskiego znajomości świata starożytnego, wyrażanego w prawdzie, w jego języku, i zarazem otwieranego problemowo na bliską nam wówczas i w perspektywie historycznej ukazywaną rzeczywistość życia. Koncepcja łaciny żywej i pozbawionej wyjałowiającej nudy ${ }^{78}$.

Ten właśnie dydaktyk zaszczepił w Parandowskim miłość do Cycerona, zadając uczniom jako lekturę domową Sen Scypiona (Somnium Scipionis). Jak prozaik wyznawał po latach, wtedy właśnie „Lody prysły. W tej wizji zaświatów Cyceron przemówił do mnie jak nigdy dotąd” (L 193). Później Szczepański zaprosił byłego ucznia, miłośnika kultury i literatury antycznej, do współpracy przy pisaniu kompendium Kultura klasyczna $w$ zarysie (1931). Po prawie 50 latach na kartach dziennika Parandowski zanotował:

Często wracam pamięcią do lat szkolnych i z głęboką sympatią odnajduję we wspomnieniu wiecznie żywe postaci moich nauczycieli. Myślę o nich z szacunkiem i wdzięcznością. Jeśli miałbym jednego z nich wyróżnić, sądzę, że byłby nim Jan Szczepański, który przez cztery lata, od piątej klasy gimnazjalnej do matury, uczył mnie łaciny, wtajemniczając jednocześnie w świat kultury klasycznej. Po latach spotkaliśmy się w tym właśnie świecie, opracowując wspólnie obraz kultury klasycznej, i na tej książce nasze dwa nazwiska są złączone. To rzadki przykład wiernego sojuszu z doskonałym nauczycielem. [L 268] 
Do ulubionych lektur gimnazjalnych przyszłego pisarza należały też dialogi Platona: Eutyfron, Uczta, Fajdros, Gorgias, oraz Listy Cycerona, czytane i komentowane w języku oryginału. Teksty Ateńczyka odkrywały przed młodzieńcem ład i harmonię, te autorstwa Rzymianina ujawniały zaś wrażliwość współczesnego człowieka, niwelując dzielący go od czytelnika przedział 2000 lat. Zapewne właśnie owe lektury sprawiły, iż w przyszłości Parandowski w swojej prozie zawsze będzie stosował zasadę ładu i umiaru, która stanie się cechą wyróżniającą jego pisarstwo. I choć nie wszystko u starożytnych budziło zachwyt gimnazjalisty, to okres „między świtem Grecji a zachodem Rzymu" miał dla Parandowskiego zawsze szczególny urok. Po kilku dekadach wspominał on na łamach „Meandra”: „Opuszczałem [...] gimnazjum $\mathrm{z}$ głęboką namiętnością do antyku, brałem ją po prostu jako fakt, którego nic już nie zmieni” ${ }^{79}$.

Latem 1913, na rok przed Wielką Wojną, mającą radykalnie wpłynąć na losy świata, Parandowski zakończył gimnazjalną edukację jako jeden z najlepszych uczniów. Miał wszakże świadomość, że tak wysoką lokatę zawdzięcza niezwykłej życzliwości nauczyciela matematyki, profesora Kazimierza Strutyńskiego. „Królowa nauk" stała się zmora przyszłego pisarza do tego stopnia, że w ostatnich klasach gimnazjum profesor nie pytał go nigdy - w słusznej obawie, iż „odpowiedź jego samego okryje hańbą" 80 . Co więcej, pomógł również Parandowskiemu wyjść obronną ręką na egzaminie maturalnym:

Zadanie maturalne zakomunikowano mi w sekrecie dzień naprzód, zrobiłem je z pomocą przyjaciela, wyuczyłem się na pamięć, przed komisją egzaminacyjną stanąłem pewny siebie i w mgnieniu oka pokryłem tablicę mnóstwem cyfr i liter, jakby duch Gaussa wrócił na ziemię, wcieliwszy się we mnie. Niestety, wmieszał się w to profesor, który zadał mi pytanie, pozostające w niewątpliwym i łatwym związku z moją wyborna praca na tablicy, lecz to pytanie zaskoczyło mnie jak somnambulika nagły okrzyk. Przez chwilę groziła katastrofa, było aż nadto widoczne, że nie wiem, co to jest „mantysa”. Profesor sam wrychle dał mi się wymknąc $z$ zasadzki ${ }^{81}$.

W Wykazie abiturientów, którym przyznano świadectwo dojrzałości w terminie letnim $1913^{82}$ przy nazwisku Parandowskiego w rubryce „Religia” wpisano „greckokatolicka”, a w rubryce „Zamierzone studia dalsze” - „Wydział Filozoficzny”.

$Z$ galicyjskiego gimnazjum przyszły autor Mitologii wyniósł zaszczepiony przez nauczycieli kult dla świata starożytnej kultury i obyczajowości, zainteresowanie dla nauk humanistycznych i szacunek dla sztuki. Nauczycielom tamtejszym zawdzięczał swój fundament intelektualny. Tu rozwinęły się pasje naukowe Parandowskiego, którym już od młodości oddawał się on z zapamiętaniem. W murach placówki zdobywał pierwsze szlify pisarskie i odczuwał dumę na widok opublikowanych własnych tekstów. Opuszczał szkołę w przekonaniu, iż jego przeznaczeniem sa toga i biret uniwersytecki ${ }^{83}$.

W latach profesury na Katolickim Uniwersytecie Lubelskim głosił Parandowski,

J. Pa r a nd ow ski, Antyk i ja. „Meander” 1954, nr 5, s. 199.

Jak się uczyli wspótcześni, wybitni pisarze polscy. Jan Parandowski, s. 7.

Ibidem.

Zob. Sprawozdania Dyrekcji C. K. IV Gimnazjum we Lwowie za rok szkolny 1913, s. 82.

Zob. Jak się uczyli wspótcześni, wybitni pisarze polscy. Jan Parandowski, s. 7. - J. P a r a n d ows ki: Antyk i ja, s. 198; Wspomnienia i sylwety. Wrocław 1960, s. 196. 
że maturzysta po dawnym klasycznym gimnazjum galicyjskim więcej umiał z łaciny i greki niż współczesny absolwent filologii klasycznej ${ }^{84}$. Zalety edukacji klasycznej cenił przez całe życie i ubolewał nad poziomem wykształcenia współczesnych humanistów, szczególnie - umiejętności swobodnego korzystania z tekstów autorów starożytnych:

Ja w gimnazjum uczyłem się łaciny i greki w tak szerokim zakresie, jaki się dzisiaj wydaje wręcz nieprawdopodobny. Wiele temu zawdzięcza struktura mojego umysłu i nie wyobrażam sobie, jak bym się mógł obejść bez bliskiego współżycia ze światem, z którego pochodzą najwznioślejsze natchnienia. To współżycie wyraziło się w moich książkach, tematy antyczne tam nieomal przeważają. [P 32]

\section{Abstract \\ GRAŻYNA PAWLAK Institute of Literary Research of the Polish Academy of Sciences, Warsaw \\ UNKNOWN FACTS FROM JAN PARANDOWSKI'S BIOGRAPHY}

The aim of the article is a presentation of effects of research in Jan Parandowski's biography carried out in Ukrainian and Polish archives. It is an attempt at answering the questions strictly connected with Parandowski's still unexamined life history, especially those linked to the Lvov period of his life. The analysis scrutinizes a number of church and state documents; the writer's memories are also verified while reaching for other witnesses' relations. The papers preserved in Ukrainian archives allowed to explain a number of issues including such ones about which Parandowski himself remained silent or, when questioned for them, he effectively misguided the former scholars. The paper establishes, who the writer's parents were, especially his father about whom Parandowski never mentioned though they lived under one roof for 25 years. The archive search query connected with exploration of written sources not only helped to figure out the threads of family relations, but also to interpret them in the social context. In this mode the paper also proves that the experience of the prewar Lvov multiethnicity and multiculturality coupled with the humanistic education of the Galician school exerted influence on the future writer's development of interest. Owing to it, Parandowski's biography's hardly known fragment becomes accessible for the contemporary reader. 2004, s. 229. 